\title{
F.A. HAYEK AND WHY GOVERNMENT CAN'T MANAGE SOCIETY
}

\author{
RICHARD M. EBELING*
}

Fecha de recepción: 6 de junio de 2015.

Fecha de aceptación: 13 de septiembre de 2015.

This year marks the seventieth anniversary of the end of the Second World War. On May $8^{\text {th }}$, Nazi Germany surrendered to the Allied Powers in Europe. On September $2^{\text {nd }}$, Imperial Japan surrendered to the Allies on the deck of the U.S.S. Missouri in Tokyo Bay, thus ending a global conflict that is estimated to have cost the lives of upwards of 50 million people.

In autumn of 1945, everyone was looking forward, finally, to a world at peace that could recover from the destruction of a catastrophic war and move towards a bright new future. But what kind of world was it to be?

Nazism and fascism had been militarily and ideologically pulverized in the conflict. No one wanted to goose-step to Hitler and Mussolini's grandiose dreams of a world-ruling master race or a war-worshipping aggressive nationalism to which innocent human beings were to be sacrificed.

* Richard Ebeling is currently the BB\&T Distinguished Professor of Ethics and Free Enterprise Leadership at The Citadel in Charleston, South Carolina. The text is based on a talk given on a panel session devoted to «Friedrich Hayek as Defender of Liberty» at the Tenth Annual Moral Foundations of Capitalism Conference sponsored by the Clemson Institute for the Study of Capitalism at Clemson University in South Carolina, May 29, 2015. 
I

\section{THE POSTWAR HOPE FOR A BETTER WORLD THROUGH SOVIET SOCIALISM}

Instead, many looked East to the Soviet Union that stood as the new colossus that had born the brunt of the Nazi war machine; Soviet socialism seemed to offer a vision of a «better world» free from economic exploitation or class distinction.

Before the war, under Comrade Stalin's bigger-than-life leadership, socialist central planning and a spirit of serving the «common good» of humanity seemed to be creating a colossal industrial society in what had been the backwards agricultural nation of Russia a mere handful of years before. This was all being done, Soviet propaganda assured, for the benefit of the mass of the workers, and not a handful of greedy plundering capitalists. A people's utopia was in the making.

The German invasion had destroyed many of the industrial centers in European Soviet Russia. But beyond the Ural Mountains, Stalin had directed the reconstruction of new industrial centers that had ground out vast amounts of military hardware and equipment that stopped the Nazi onslaught, and had brought the Soviet Army to the central of Europe, with the red flag raised over Warsaw, Budapest, Vienna, Berlin and Prague.

Marxian ideology (and prophecy) asserted the inevitability of the coming socialist society. Communist parties both within the orbit of Stalin's new empire in Eastern Europe and in the Western democracies outside of Stalin's grasp were all at work to bring the totalitarian collectivist future to pass.

II

WESTERN SOCIALISTS WANTED SOCIALISM WITH A DEMOCRATIC FACE

Of course, not all socialists in the West were slavish servants to the Master in Moscow the way the communist parties were so bound. Many Social Democrats believed that democracy was both compatible with and an essential complement to a humane socialism, 
a socialism that did not reduce humanity to obedient cogs in a giant collectivist wheel directed by a «dictatorship of the proletariat.» They wanted socialism with traditional civil liberties, personal freedom and democratic politics.

It is important to remember, however, that at a fundamental level the conflict between Western European democratic socialists and Moscow-managed single-party communists on opposite sides of the European divide was a dispute over means and not ends.

III

SOVIET COMMUNISTS AND SOCIAL DEMOCRATS ALL WANTED CENTRAL PLANNING

In the years before, during, and immediately after the war, the dispute and debate was over two things: How shall the socialist society come about: through ballots or bullets - through democratic elections or violent revolution? And once in power, would socialist rule and control be maintained through multi-party democratic choice or on the basis of one-party dictatorship with the suppression of civil liberties?

But both Western socialists and Soviet-style communists, nonetheless, still agreed about the end to be attained: near or full abolition of private ownership of the means of production and the implementation of government central planning of production and distribution in the place of decentralized and competitive private enterprise.

IV

MOST AMERICAN LEFTISTS PUSHED FOR INTERVENTIONIST-WELFARE STATISM

The United States, of course, was noticeably different. The socialist ideal of nationalization and central planning had never caught the imagination or the political traction that such ideas possessed in Europe. In spite of America's flirtation with economic fascism during FDR's early New Deal days and the wartime planning under 
which virtually the entire U.S. economy was put into the straightjacket of government control, the postwar direction was for the freeing of the market from total and direct government planning.

In America, outside of the more consistent and vocal voices on «the left,» the debates focused on the degree to which U.S. industry needed to be regulated by the government to tame tendencies toward supposed monopolistic and oligopolistic inefficiencies and distortions in the market; the extent to which New Deal-introduced welfare state programs should be enlarged and extended; and, of course, the requirements for activist fiscal and monetary policies to assure and maintain «full employment» inspired by the virtual monopoly dominance of Keynesian ideas in all matters of macroeconomic theory and policy.

\section{$\mathrm{V}$ \\ F. A. HAYEK WAS CRITIC OF KEYNES AND AUTHOR OF THE ROAD TO SERFDOM}

But in that same September of 1945, now seventy years ago, there appeared a lead article in the American Economic Review, the leading journal of the American economics profession, on «The Use of Knowledge in Society,» by an «Austrian» economist named Friedrich A. Hayek who had been teaching at the London School of Economics for almost a decade and a half.

Born in Austria and having graduated from the University of Vienna, in the 1930s Hayek was recognized as the leading opponent and contender against the ideas of the Cambridge University economist, John Maynard Keynes, and his emerging «Keynesian» economics. Hayek was also acquiring a international name recognition from a book he had published a year earlier in 1944, The Road to Serfdom.

The theme of The Road to Serfdom is that while socialism had been promised as a «new world» of freedom and prosperity for all with an abolition of capitalist exploitation, the inescapable concentration of power and control in the hands of a socialist government so to centrally plan the economic affairs of the society would lead to the threatened loss of not just economic freedom with the end of private property, but the loss of personal and civil liberties as well. 
Running through his damning indictment of the political and personal consequences from imposing full socialist planning on society, is a defense of the dignity and sanctity of the individual as a human being. The importance of private property is argued to be essential to secure and protect all freedom from the grasping hand of political power, and the crucial role of the existence, practice and respect for an impartial rule of law is emphasized for the guardianship of people from arbitrary government control.

VI

HAYEK'S «USE OF KNOWLEDGE IN SOCIETY» AND THE UNWORKABILITY OF PLANNING

There are several concise and suggestive passages in The Road to Serfdom in which Hayek points out fundamental weaknesses in the practical ability of a central planning system to effectively replace a functioning competitive market order for solving the «economic problems» of society. But it is only in his 1945 article on «The Use of Knowledge in Society» that Hayek details what he considers to be the essential difficulty with any comprehensive system of economic planning.

If central planning were to work, it would be necessary for the central planners to possess complete and comprehensive knowledge of all the relevant «data» to decide how best to use and allocate all the diverse physical resources, human labor skills, and technical possibilities so to produce those goods best serving the wants of the members of society, and in the most efficient manner to get the most out of the scarce means available to satisfy people's ends.

Hayek's starting point was to emphasize that all of that meaningfully relevant «data» exists in no one place and in no one mind or group of minds. The «knowledge of the world» is dispersed and divided up in the minds of all the members of society, with each knowing and understanding only a small part relative to all the knowledge that exists in everybody's minds, combined.

Furthermore, while people often think of knowledge in the textbook or «scientific» sense, there are other types of knowledge no less relevant or important that must be utilized and brought to bear 
if production is to proceed effectively and efficiently and if what is supplied tends to match what members of society want to demand.

VII

DECENTRALIZED KNOWLEDGE AND NEED TO COORDINATE ALL THAT PEOPLE KNOW

Hayek called this other type of knowledge the «local knowledge of time and place.» This is the knowledge that is only acquired working and interacting within a particular corner of the social system of division of labor. This knowledge comes from working in a particular trade, in a specific firm or enterprise, working with a distinct group of other people, in which particular machines and tools are used as the means to satisfy specific consumers and demanders in the attempt to gain and keep their business in a competitive market.

But if knowledge is decentralized in a complex system of division of labor in which people are invariably separated from each other by both time and space, how shall information be communicated among people so their choices and actions on the production side of the economy can be tending to match and coordinated with the consumption side of the market?

Hayek forcefully argued that it is not necessary for all the multitudes of millions (now billions) of participants in the division of labor to directly know each other and each other's planned actions and desires to interpersonally coordinate all that they do. And it is certainly impossible for a handful of central planners to know enough of all that there is to know to successfully perform such an intricate and ever-changing task.

\section{VIII \\ THE ROLE OF MARKET-BASED PRICES TO SOLVE SOCIETY'S KNOWLEDGE PROBLEM}

The market solves the «economic problem,» which Hayek emphasized was really the problem of how to utilize all the knowledge in the world when all that knowledge can never be coordinated for effective use other than through the competitive price system. 
Through the prices they offer to pay, demanders from one corner of the globe to another register their interest and their degree of willingness to pay others to supply them with the various goods, services, and resources they are interested in obtaining from those willing and able to supply.

At the same time, every producer anywhere in the world is saved the necessity of needing to know all the other competing producers and enterprisers who also may have investment goals in mind involving the acquisition and use of various types of labor, capital equipment and raw materials.

It is sufficient that those rival demanders for the means of production on the producer-side of the market indicate and register their interest, willingness and ability to demand those factors of production through the prices they offer to purchase, hire or employ them.

These input prices inform producers anywhere in the world what the relative costs shall be to use those factors of production in their own line of activity, and therefore which combination of them would incur the least monetary expense to employ relative to the anticipated price they think consumers might be willing to pay for the finished product they could assist in producing.

These prices on the demand side of the market enable everyone in their own corner of the society to decide how best to allocate their limited income among alternative consumer goods they might purchase; and those prices on the supply side of the market assist each and every producer in deciding whether production of some product might earn a profit or suffer a loss, and if possibly profitable, with what combination of inputs to minimize expenses given other desired uses for them in other parts of the market.

IX

MARKETS ENABLE BOTH FREEDOM AND USE OF KNOWLEDGE

The advantage of using a market-generated network of competitively established prices is that they not only inform everyone about the demand and supply potentials of others in society. It also 
means that every individual may be left free to make his own decisions about how best to use that knowledge of his local time and place in the most effective manner, so all may benefit from what each knows and can do that no central planner could ever know or do better than the decentralized decision-makers themselves.

Thus, individual liberty and social coordination - freedom and order - become not only possible, but can be shown to be indispensible if the «knowledge of the world» is to be brought into play for the mutual benefit and advantage of all.

If personal freedom is considered to be a desirable human condition and if human cooperation for mutual improvement is considered of value for the material and cultural betterment of mankind, then it can be shown, Hayek concluded, that only free markets - competitive capitalism - can solve the «economic problem» of the use of knowledge in society.

Socialist central planning, therefore, with its concentration of control over the means of human existence in the hands of the political authority, is not only a threat to human freedom and dignity - a «road to serfdom» - but it could also be shown to be an economic dead end offering neither productive efficiency nor the practical utilization of the division of knowledge that accompanies a system of division of labor.

Abolition of private property in the means of production not only results in the personal loss of the means for existence and betterment outside of the power of government, with its danger of tyranny. It limits mankind's opportunities and progress to what a small number of finite minds can master and know, who are assigned the task of centrally planning and commanding the productive activities of the society.

Hayek's argument on the essential limits of the human mind to know enough to reconstruct and plan society according to a crafted central design was and is a powerful critique against the socialist ideal of the last one hundred years.

Which one of us, if we spoke with all honesty and truthfulness, can assert that they know enough to plan the economic and related social activities of the over 320 million distinct individuals living in the United States, or the more than 7.2 billion people who live on our planet? 
But it might be said that «socialism» in his older and original form is now dead. It died with the fall of the Berlin Wall in 1989 and the collapse of the Soviet Union in 1991. Except, maybe, in North Korea, the case for and the practice of central planning has become something of the past, a tragic historical curiosity that historians will analyze and try to understand for a long time.

Today around the world practically every country operates with forms of a market economy. Some may be more free and competitive while others a less so, but «the market» as the broad institutional framework in which economic affairs go on in daily life is now virtually universal.

\section{$X$ \\ HAYEK'S MESSAGE ABOUT PRICES STILL RELEVANT IN A POST-SOCIALIST WORLD}

Hayek and other thinkers like him have won. Socialist central planning is died, relegated, to use Marx's phrase, to the «dustbin of history.» The issues confronting societies, now, is not markets versus planning. But the degree and forms that markets will take on, and in this setting the degree to which governments regulate and intervene into the workings of the market system.

Influencing and moving markets in one direction compared to another through government regulatory and fiscal policies are a far cry, it is said, from the «old days» of those calling for and predicting the «end of capitalism.»

But a logical extension of Hayek's argument is that any interferences with the price system or the autonomy of market participants to act on their best judgment in their respective local circumstances of time and place must necessarily prevent the «knowledge problem» of economic coordination from being most effectively solved.

Prices, in other words, need to be able to tell the truth: What are the actual demands of market participants for various consumer goods and services, and what are the actual availabilities and alternative demands for the scarce means of production with which those desired consumer and other goods may be manufactured 
(what economists called the «opportunity costs» of the land, resources, labor and capital in their competing uses on the supply-side of the market)?

\section{XI \\ INTEREST RATE MANIPULATE DISTORTS SAVINGS AND INVESTMENT DECISIONS}

Market rates of interest represent a critical network of prices. Hayek made his early reputation as a money and business cycle theorist in opposition to Keynes' policy proposals for «activist» monetary and fiscal policy.

Hayek argued that market-based interest rates are critical for coordinating the decisions of income earners concerning how much of their income and wealth to divide between consumption and savings with the decisions of potential borrowers desiring to use the savings of others to undertaken time-consuming investment projects that will bring forth desired consumer goods at some point in the future.

Monetary central planners through the central banking system attempt to influence interest rates and the types and amounts of investment spending through increasing the quantity of money in the banking system. The artificially lowered interest rates reduce the cost of borrowing and raise the prospective profitability of possible investment projects that would not have seemed worth undertaking at a higher market-established rate of interest.

The increase in the money supply creates the illusion that there is more savings available to be borrowed to start, complete and sustain investment projects than there are actual real saved resources to do so.

Borrowers and investors are misinformed by an important market signal to use their special and localized knowledge of time and place in misdirected ways that are inconsistent and eventually unsustainable with the real amount and types of scarce resources with which to undertaken their investment projects, given people's actual decisions to save portions of their income, and thus «free up» a certain amount of resources for future-oriented production. 
Precisely because the multitudes of individuals participating in the social system of division of labor cannot know all the others with whom they are interdependent in the complex networks of supply and demand, and therefore directly know what others are planning to do with their income and resources, everyone is dependent on the truthfulness of the price system through which all those individuals coordinate their diverse decisions and actions.

By falsifying interest rates - the intertemporal prices connecting savings choices with investment decisions - governments potentially set in motion distortions and imbalances in the use of resources, capital and labor that manifest themselves in the form of the business cycle.

Government manipulation of prices, therefore, can be just as disruptive as the abolition of prices by political edict. Just as automobile traffic on the road system would be chaotic if the traffic lights were turned off, it can be equally disruptive and dangerous if red lights are turned to green when the perpendicular traffic at an intersect is simultaneously given a green light signal as well.

\section{XII \\ MINIMUM WAGE LAWS CAUSE UNEMPLOYMENT AND DISTORT RESOURCE USE}

The same applies with the recent political push to raise the U.S. minimum wage law from its current level to $\$ 15$ per hour or more. Critics of the minimum wage increase have rightly emphasized that doing so will potentially drive many marginal workers out of their existing jobs and prevent other jobs from ever materializing.

Setting a minimum wage below which no worker may be legally employed runs the risk of pricing out of the market those unskilled or low-skilled workers who employers find contribute a value to their production activities less than what the government mandates they are to be paid.

None of us pays more for something than we think it to be worth. This applies no less to employers whose only means of paying those they employ are the revenues they earn from selling products and services to the buying public. For an enterpriser to 
remain in business, costs of production cannot persistently be above the revenues received from sales of goods and services to consumers. Labor costs are no less a determinant of profit or loss than other expenses of doing business.

But besides this, the manipulation of wage rates through minimum wage laws also influence and disrupt the use of scarce resources in comparison to their allocation in a purely market-determined network of wages for different types and skills of labor.

\section{XIII \\ MINIMUM WAGE CAN RESULT IN CAPITAL REPLACING LABOR WHEN NOT NEEDED}

A number of both advocates and critics of a minimum wage increase have pointed out that some businesses have suggested that raising labor costs in this manner may result in replacing some workers with capital.

Computer tablets at restaurant counters can replace waiters and waitresses in taking orders conveyed to the cooks and chefs in the kitchen (as has already been happening in some places). And in Japan they have even been experimenting with robots that bring food orders to the counter or the restaurant tables in place of human servers.

All of this may end up being a market-based «wave of the future» to the extent that an aging and retiring population makes certain types of labor more scarce and expensive to employ over time. The demands for labor and their rising cost of employment over many decades in the twentieth century was a major factor behind the reduction in domestic servants in middle class households and their replacement with laborsaving home appliances and conveniences to do everyday housework.

Another example is how the greater cost efficiencies of office and laptop computers resulted, over time, in the disappearance of large numbers of secretaries employed in the «typing pools» of many large and small businesses throughout the economy.

By artificially rising the price and therefore the cost of certain types of labor through minimum wage legislation, the price sys- 
tem for workers no longer is fully telling the truth about who is available for work and at what market-determined wages to assist producers and enterprisers on deciding what would be the most appropriate use and combinations of labor and capital given the real, underlying supply and demand conditions in the market.

Capital that would be more profitably and efficiently utilized in other sectors of the economy will be drawn into these labor-saving activities due to the government imposing this wage floor for labor. This may occur, as a consequence, years or decades before the market would have determined that this was the best use for scarce laborsaving capital resources, and in some cases when it might never have been profitably desirable to redirect capital into those uses if not for the minimum law.

So by manipulating workers' wages through minimum wage legislation, people will, again, potentially make misdirected decisions on how best to use their local knowledge of their own particular place and circumstances in the market because the price of hiring labor will not be telling the truth.

\section{XIV \\ GOVERNMENT REGULATIONS PREVENT THE USE OF PERSONAL KNOWLEDGE}

This is no less the case with government production regulations and restrictions. In a dynamic market, individuals are constantly coming up with new ideas based on changing supply and demand situations that create the incentives and profit-oriented alertness to discover and imagine new possibilities about what products to produce and how to produce them.

In a world in which change seems to come swift and fast, flexibility and adaptability to such change are keys to business success in meeting and beating the competition in capturing consumer sales. Compare the market world of today with that of twenty or ten or even five years ago, and you see the technological discoveries and applications that have transformed everyday life in ways that we often forget to fully appreciate since they have already become so taken for granted. 
It has been pointed out that in the U.S. the private sector spends about $\$ 2$ trillion a year on compliance with government regulations, which in the Code of Federal Regulations take up over 175,000 pages of rules, commands, restrictions and prohibitions. Businessmen and those they employ must apply their knowledge and time to meet the demands of politicians and bureaucrats rather than utilizing them toward consumer-oriented production, innovation, and improvement in all that their enterprises do.

At the same time, these thousands of pages of regulations serve as straightjackets that limit and inhibit entrepreneurial ability to take advantage of the changing circumstances of time and place because any and all responses, changes and adjustments are confined within the existing permissible rules and regulations imposed on the marketplace.

Of course, appreciating the full impact of this is impossible to completely know precisely because it is part of what Frederic Bastiat explained as the «unseen.» All those market activities and outcomes that never occur, or at least not in their entirety, because the regulatory structure prevents or modifies all the forms they would have taken on in a more free market institutional environment.

That we cannot fully see or know all of these «might-havebeens» if not for government regulation does not any the less change the fact that individuals in the marketplace are prevented or restricted in how best to use the knowledge that they only possess and which the government regulators can never know or appreciate in the same way each of the individuals in the market do in their respective places in the division of labor.

\section{$\mathrm{XV}$}

\section{THE MORE COMPLEX THE SOCIETY, THE LESS GOVERNMENT CAN DO SUCCESSFULLY}

Another way of saying all of this is that Hayek challenged the entire trend of collectivist thinking and policy advocacy — whether in the form of central planning or price and production interven- 
tionism - by emphasizing the limits on what man can successfully command and control in the social and economic order of things.

For decades the socialists and interventionists had argued that the more complex the society the less it could be left to the unhampered workings of the market system. The more intricate the social order and people's relationships in it, the more there needed to be a centralized political guiding hand to assure that it did not fall into chaos and disharmony.

Hayek turned this argument on its head. He insisted that the more complex the social and economic system the less any single or handful of human minds could comprehend, master or manipulate the relationships for better outcomes than when the market was left free.

If we wish to use all of that ever more complex «knowledge of the world» for the benefit of all, we must leave alone those who possess it in decentralized fragments, and who know best its use through their own actions and interactions in their corners of society. We need to allow all of that dispersed knowledge to be effectively coordinated in an increasingly global community of commerce, culture, and creativity through the mechanism of competitively formed market prices to give each the minimal amount of necessary information about all the others with whom they are interdependent so to integrate what each does with the actions of everyone else.

In «The Use of Knowledge in Society» Hayek summarizes his argument:

«We must look at the price system as ... a mechanism for communicating information if we want to understand its real function ... The most significant fact about this system is the economy of knowledge with which it operates, and how little the individual participants need to know in order to be able to take the right action ...

It is more than a metaphor to describe the price system as a kind of machinery for registering change, or a system of telecommunications which enables individual producers to watch the mere the movement of a few pointers, as an engineer might watch the hands of a few dials, in order to adjust their activities to change of which they may never know more than is reflected in the price movement.» 
Hayek went on to refer to the «marvel» of all the complex knowledge and actions of multitudes of millions of people the price system successfully and constantly tends to coordinate even in the face of continual unanticipated and uncertain change.

Hayek said:

«I have deliberately used the word 'marvel' to shock the reader out of the complacency with which we often take the working of this mechanism for granted. I am convinced that if it were the result of deliberate human design, and if the people guided by the price change understood that their decisions have significance far beyond their immediate aim, this mechanism would have been acclaimed as one of the greatest triumphs of the human mind.»

Of course the competitive price system is not the creation or design of a grand council or benevolent king. Trade, competition and prices emerged «spontaneously» out of people searching for avenues and opportunities to improve their circumstances through discovered mutually advantageous exchange.

\section{XVI \\ THE SIGNIFICANCE OF HAYEK'S CONTRIBUTION TO HUMAN KNOWLEDGE}

The fact that the market price system has emerged and evolved over centuries and not been created by the fanfare of a political command makes most people not even realize its importance, with it being taken for granted like language, or customs and manners, all of which makes society and social life possible but are also not the designs of political leaders.

Looking over the last seven decades since the appearance of Hayek's «Use of Knowledge in Society,» we can now appreciate that in retrospect it represents one of the most important contributions to man's understanding of how the world in which he lives and works is made possible without the guiding hand of government command. 
And just how relevant his argument remains today in the face of political regulations and controls that prevent that «marvelous» price system from most effectively integrating and coordinating the actions of billions of people whose freedom to use their own bits of unique knowledge and knowhow is critical for the continuing advancement of mankind. 